\title{
Pengaruh Elektrolit Terhadap Sinyal Pada Sensor Pestisida
}

\author{
Afifah Muhimmatul Mustaghfiroh ${ }^{1}$, Dhody Pazar Ramadani ${ }^{1}$ dan Ani Mulyasuryani ${ }^{1 *}$ \\ ${ }^{1}$ Jurusan Kimia, Fakultas Matematika dan Ilmu Pengetahuan Alam, Universitas Brawijaya \\ Jl. Veteran, Malang, 65145, Indonesia \\ *mulyasuryani@ub.ac.id
}

\begin{abstract}
Abstrak
Telah diteliti pengaruh elektrolit terhadap sinyal sensor pestisida menggunakan sensor diazinon dan sensor klorpirifos. Sensor menggunakan reseptor molecularly imprinted polymer (MIP) poli vinil alkohol (PVA)$\mathrm{Fe}_{3} \mathrm{O}_{4}$. Komposisi reseptor MIP PVA- $\mathrm{Fe}_{3} \mathrm{O}_{4}$ untuk sensor diazinon adalah PVA 70,19 \%; $\mathrm{Fe}_{3} \mathrm{O}_{4} 1,72 \%$; glutaraldehid 12,48 \%; asam sitrat 15,59\% dan diazinon 0,02 \%. Komposisi reseptor MIP PVA- $\mathrm{Fe}_{3} \mathrm{O}_{4}$ untuk sensor klorpirifos adalah PVA 82,8 \%; $\mathrm{Fe}_{3} \mathrm{O}_{4}$ 0,5\%; glutaraldehid 7,4 \%; asam sitrat 9,2 \% dan klorpirifos $0,1 \%$. Reseptor dilapiskan pada permukaan screen printed carbon electrode (SPCE). Besaran sinyal yang terbaca adalah potensial listrik dimana pembacaannya dibandingkan terhadap $\mathrm{Ag} / \mathrm{AgCl}$. Pengukuran diazinon dilakukan pada pH 2 dan pH 6 untuk klorpirifos, keduanya dalam $\mathrm{HCl}$, buffer fosfat dan buffer fosfat-KCl. Hasil penelitian menunjukkan bahwa jenis elektrolit berpengaruh terhadap penurunan sinyal. Penurunan sinyal menyebabkan peningkatan kepekaan sensor. Kepekaan dari sensor diazinon adalah $33,8 \mathrm{mV} /$ dekade pada $\mathrm{pH} 2$, dalam buffer fosfat $-\mathrm{KCl}$, rentang konsentrasi $10^{-5}-10^{-12} \mathrm{M}$, dan waktu respon 150 detik. Kepekaan sensor klorpirifos adalah $24 \mathrm{mV} /$ dekade pada $\mathrm{pH}$ 6, dalam buffer fosfat, rentang konsentrasi $10^{-6}-10^{-13} \mathrm{M}$, dan waktu respon 150 detik.
\end{abstract}

Kata Kunci: elektrolit, , diazinon, klorpirifos, molecularly imprinted polymer, sensor kimia

\section{Pendahuluan}

Pestisida secara umum banyak digunakan dalam dunia pertanian untuk mengurangi kerusakan hasil pertanian serta meningkatkan hasil produksi pertanian. Namun, penggunaan pestisida dampak buruk terhadap kesehatan manusia dan hewan [1]. Organofosfat merupakan salah satu jenis pestisida yang mempunyai resiko paling besar terhadap kesehatan manusia [2]. Diazinon dan klorpirifos merupakan golongan organofosfat yang sulit larut dalam air dan mudah terpartisi ke dalam fasa organik sehingga keduanya dapat ditemukan dalam hasil-hasil pertanian [3]. Batas diazinon dan klorpirifos yang diperbolehkan pada hasil pertanian berupa wortel adalah $0,5 \mathrm{mg} / \mathrm{kg}$ [4]. Jika kedua senyawa tersebut ditemukan berlebih pada residu hasil pertanian, maka akan menghalangi kinerja enzim kolinesterase sehingga dapat mengganggu kesehatan [5]. Oleh karena itu, dibutuhkan suatu metode untuk menganalisis kadar diazinon dan klorpirifos dalam hasil pertanian.

Sensor kimia merupakan suatu perangkat untuk merespon analit tertentu melalui reaksi kimia. Sensor kimia secara umum terdiri dari reseptor, transduser dan detektor. Reseptor merupakan bagian penting dalam sensor kimia untuk mengenali analit secara selektif. Reseptor yang telah banyak dikembangkan adalah membran selektif [6]. Salah satu membran selektif yang banyak dikembangkan saat ini adalah molecularly imprinted polymer (MIP). MIP telah banyak dikembangkan untuk meningkatkan selektivitas dari sensor kimia [7]. MIP sebagai reseptor telah banyak dikembangkan untuk mendeteksi klenbuterol [8], hidroksizin [9], kokain [10] dan melamine [11]. Dengan demikian, pada penelitian ini sensor pestisida diazinon dan klorpirifos dibuat menggunakan reseptor MIP. 
Molecularly imprinted polymer (MIP) tersusun atas molekul tercetak, monomer fungsional dan pereaksi pengikat silang [7]. Penggunaan monomer fungsional memerlukan pelarut volatil sehingga dapat digantikan dengan polimer [12]. Pada penelitian ini, reseptor MIP tersusun atas molekul tercetak diazinon (sensor diazinon), molekul tercetak klorpirifos (sensor klorpirifos), polimer PVA, pereaksi pengikat silang glutaraldehid dan katalis asam sitrat. PVA dapat digunakan sebagai polimer dalam pembuatan reseptor MIP karena PVA dapat larut dalam air [12]. Penambahan material pendukung $\mathrm{Fe}_{3} \mathrm{O}_{4}$ dalam pengembangan sensor kimia telah banyak dikembangkan. $\mathrm{Fe}_{3} \mathrm{O}_{4}$ merupakan suatu material yang bersifat super paramagnetik, konduktif dan pseudokapasitif [13]. Modifikasi MIP dengan $\mathrm{Fe}_{3} \mathrm{O}_{4}$ telah digunakan untuk mendeteksi gemifloksasin mesilat [14], glifosat [15] dan hidroklorotiazida [16]. Penggunaan $\mathrm{MIP}-\mathrm{Fe}_{3} \mathrm{O}_{4}$ sebagai reseptor merupakan suatu langkah untuk meningkatkan kepekaan dari sensor kimia [7]. Oleh sebab itu, pada penelitian ini digunakan reseptor MIP-PVA- $\mathrm{Fe}_{3} \mathrm{O}_{4}$ yang dilapiskan pada permukaan elektroda kerja screen printed carbon electrode (SPCE) untuk mendeteksi pestisida diazinon dan klorpirifos

Sinyal berupa potensial sel dihasilkan dari beda potensial membran terhadap potensial pembanding $\mathrm{Ag} / \mathrm{AgCl}$ [17]. Ketika larutan diteteskan, beda potensial membran akan terbentuk pada permukaan reseptor sebagai akibat perbedaan konsentrasi antara pestisida di dalam dan diuar membran. Kemudian sinyal diteruskan ke transduser dan terbaca pada detektor. Adanya $\mathrm{Fe}_{3} \mathrm{O}_{4}$ berpengaruh terhadap pembentukan beda potensial membran. $\mathrm{Fe}_{3} \mathrm{O}_{4}$ dapat menarik ion-ion dalam larutan membentuk lapisan ganda listrik (electrical double layer) [13]. Lapisan ganda listrik yang terbentuk menimbulkan kapasitansi pada permukaan reseptor. Jika kapasitansi yang dihasilkan lebih besar, maka beda potensial membran akan mengalami penurunan dan sinyal yang dihasilkan menjadi lebih kecil. Dengan demikian, pada penelitian ini akan dipelajari pengaruh elektrolit terhadap sinyal pada sensor pestisida diazinon dan klorpirifos.

\section{Bahan}

Bahan-bahan yang digunakan dalam penelitian ini yaitu akuadem, poly vinyl alcohol (PVA), asam sitrat (CV. Kridatama, Malang, Indonesia), glutaraldehid 50\% ( Sigma Aldrich), insektisida diazinon $600 \mathrm{EC}$ (Dow), klorpirifos $200 \mathrm{EC}$ (Dursban), $\mathrm{HCl} 37 \%$ (Merck), nanopartikel $\mathrm{Fe}_{3} \mathrm{O}_{4}$, etanol (Merck), $\mathrm{FeSO}_{4} \cdot 4 \mathrm{H}_{2} \mathrm{O}$ (Sigma Aldrich), natrium hidroksida (Merck), $\mathrm{FeCl}_{3} \cdot 6 \mathrm{H}_{2} \mathrm{O}$ (Sigma Aldrich), Etanol (Merck), $\mathrm{H}_{3} \mathrm{PO}_{4}$ (Merck), $\mathrm{KH}_{2} \mathrm{PO}_{4}$ (Merck), $\mathrm{K}_{2} \mathrm{HPO}_{4} \cdot 3 \mathrm{H}_{2} \mathrm{O}$ (Merck), $\mathrm{KCl}$ (Merck).

\section{Metode}

\section{Pembuatan Sensor Diazinon dan Klorpirifos}

Larutan PVA 5\% sebanyak 0,9 mL dimasukan kedalam botol sampel. Ditambahkan larutan asam sitrat $5 \%$ sebanyak $0,2 \mathrm{~mL}$ untuk sensor diazinon dan $0,1 \mathrm{~mL}$ untuk sensor klorpirifos. Ditambahkan suspensi $\mathrm{Fe}_{3} \mathrm{O}_{4} 5 \%$ sebanyak $22 \mu \mathrm{L}$ untuk sensor diazinon dan 5,5 $\mu \mathrm{L}$ untuk sensor klorpirifos. Setelah itu ditambahkan larutan diazinon $40 \mathrm{ppm}$ sebanyak 0,3 mL untuk sensor diazinon dan larutan klorpirifos 600 ppm sebanyak 9,1 $\mu \mathrm{L}$ untuk sensor klorpirifos. Kemudian masing-masing ditambahkan glutaraldehid $4 \%$ sebanyak $0,2 \mathrm{~mL}$ untuk sensor diazinon; $0,1 \mathrm{~mL}$ untuk sensor klorpirifos dan diaduk.

Larutan campuran dipipet sebanyak $5 \mu \mathrm{L}$ dan dilapiskan pada SPCE. Setelah itu dioven selama 1 jam dengan suhu $50^{\circ} \mathrm{C}$ dan didinginkan di dalam desikator. Pengukuran menggunakan sensor diazinon dilakukan pada larutan diazinon $10^{-12}-10^{-5} \mathrm{M}$ dalam $\mathrm{HCl} \mathrm{pH} 2$, buffer fosfat $\mathrm{pH}$ 2 dan buffer fosfat-KCl $\mathrm{pH}$ 2. Pengukuran menggunakan sensor Klorpirifos dilakukan pada 
larutan diazinon $10^{-13}-10^{-6} \mathrm{M}$ dalam $\mathrm{HCl} \mathrm{pH} 6$, buffer fosfat $\mathrm{pH} 6$ dan buffer fosfat-KCl $\mathrm{pH} 6$. Pengukuran dilakukan dengan meneteskan $50 \mu \mathrm{L}$ larutan uji ke permukaan SPCE.

Tabel 1. Komposisi membran reseptor

\begin{tabular}{lcc}
\hline \multirow{2}{*}{ Komposisi } & \multicolumn{2}{c}{ Kadar di dalam membran (w/w) } \\
\cline { 2 - 3 } & Sensor diazinon & Sensor klorpirifos \\
\hline PVA 5\% & $70,19 \%$ & $82,8 \%$ \\
Asam sitrat $5 \%$ & $15,59 \%$ & $9,2 \%$ \\
Glutaraldehid 4\% & $12,48 \%$ & $7,4 \%$ \\
Suspensi $\mathrm{Fe}_{3} \mathrm{O}_{4} 5 \%$ & $1,72 \%$ & $0,5 \%$ \\
Bahan aktif & $0,02 \%$ & $0,1 \%$ \\
\hline
\end{tabular}

\section{Hasil dan Pembahasan}

Pada pengembangan sensor pestisida, telah dipelajari pengaruh elektrolit terhadap sinyal. Sensor pestisida yang dikembangkan adalah sensor diazinon dan klorpirifos. Sinyal terbentuk akibat adanya perbedaan konsentrasi antara pestisida di dalam membran dan di dalam larutan. Sinyal akan terbaca terhadap $\mathrm{Ag} / \mathrm{AgCl}$. Dalam penelitian ini, larutan elektrolit yang dipelajari untuk sensor diazinon adalah $\mathrm{HCl}$, buffer fosfat, dan buffer fosfat- $\mathrm{KCl}(\mathrm{pH} 2$ untuk sensor diazinon dan $\mathrm{pH} 6$ untuk sensor klorpirifos).

Gambar a dan b menunjukan bahwa elektrolit berpengaruh terhadap besarnya sinyal yang dihasilkan. Kekuatan ion dalam $\mathrm{HCl}$ pH 6 sebesar $10^{-6} \mathrm{M}$; buffer fosfat $\mathrm{pH} 6$ sebesar 4 x $10^{-4} \mathrm{M}$; buffer fosfat-KCl $\mathrm{pH} 6$ sebesar 4,1 x $10^{-4} \mathrm{M}$, sedangkan untuk $\mathrm{HCl} \mathrm{pH} 2$ sebesar $1 \times 10^{-2} \mathrm{M}$; buffer fosfat-KCl $\mathrm{pH} 2$ sebesar $1,6 \times 10^{-4} \mathrm{M}$; dan buffer fosfat $\mathrm{pH} 2$ sebesar $1,5 \times 10^{-4} \mathrm{M}$. Berdasarkan kurva tersebut, pada kondisi pengukuran menggunakan $\mathrm{HCl}$ menghasilkan sinyal paling besar. Hal ini dikarenakan $\mathrm{Fe}_{3} \mathrm{O}_{4}$ memiliki sifat paramagnetik sehingga dapat menarik ion $\mathrm{H}^{+}$dan $\mathrm{Cl}^{-}$yang memiliki jari-jari ion terhidrasi relatif kecil ke permukaan membran reseptor. Medan magnet yang ditimbulkan oleh $\mathrm{Fe}_{3} \mathrm{O}_{4}$ ketika berinteraksi dengan ion $\mathrm{H}^{+}$dan $\mathrm{Cl}^{-}$yang memiliki mobilitas yang baik didalam larutan dapat menimbulkan medan listrik sehingga konduktivitas membran reseptor meningkat. Sinyal pada buffer fosfat dan buffer fosfat-KCl pada kedua sensor lebih rendah daripada sinyal pada $\mathrm{HCl}$. Hal tersebut akibat dari kekuatan ion di dalam larutan, medan magnet

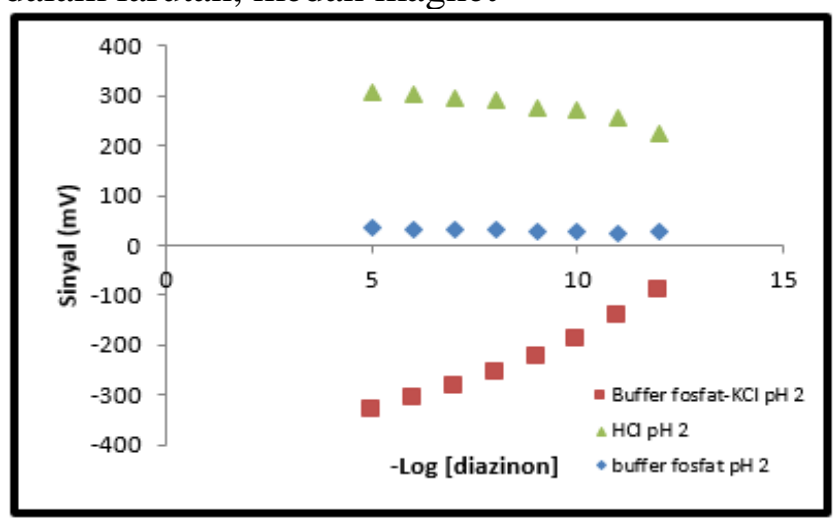

(a)

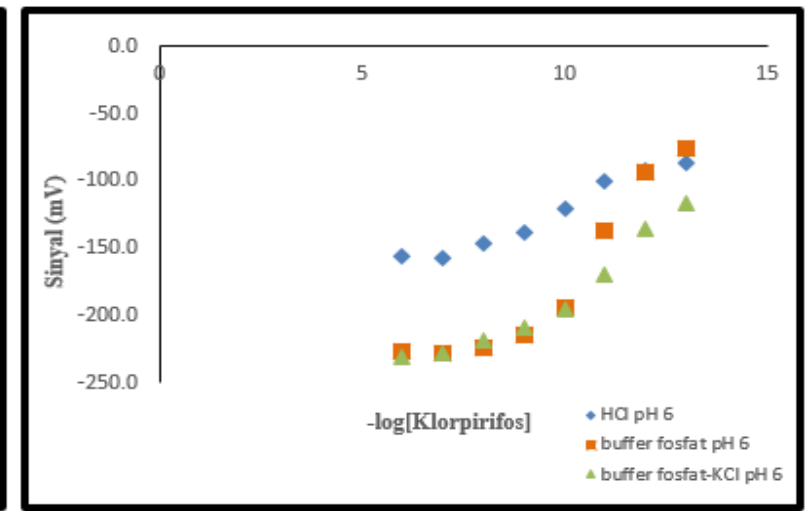

(b)

Gambar 1. Kurva hubungan antara -log [diazinon] (a) dan -log [klorpirifos] (b) terhadap sinyal

Gambar a dan b menunjukan bahwa elektrolit berpengaruh terhadap besarnya sinyal yang dihasilkan. Kekuatan ion dalam $\mathrm{HCl}$ pH 6 sebesar $10^{-6} \mathrm{M}$; buffer fosfat $\mathrm{pH} 6$ sebesar 4 x $10^{-4} \mathrm{M}$; buffer fosfat- $\mathrm{KCl}$ pH 6 sebesar 4,1 x $10^{-4} \mathrm{M}$, sedangkan untuk $\mathrm{HCl} \mathrm{pH} 2$ sebesar $1 \times 10^{-2} \mathrm{M}$; 
buffer fosfat- $\mathrm{KCl} \mathrm{pH} 2$ sebesar $1,6 \times 10^{-4} \mathrm{M}$; dan buffer fosfat $\mathrm{pH} 2$ sebesar $1,5 \times 10^{-4} \mathrm{M}$. Berdasarkan kurva tersebut, pada kondisi pengukuran menggunakan $\mathrm{HCl}$ menghasilkan sinyal paling besar. Hal ini dikarenakan $\mathrm{Fe}_{3} \mathrm{O}_{4}$ memiliki sifat paramagnetik sehingga dapat menarik ion $\mathrm{H}^{+}$dan $\mathrm{Cl}^{-}$yang memiliki jari-jari ion terhidrasi relatif kecil ke permukaan membran reseptor. Medan magnet yang ditimbulkan oleh $\mathrm{Fe}_{3} \mathrm{O}_{4}$ ketika berinteraksi dengan ion $\mathrm{H}^{+}$dan $\mathrm{Cl}^{-}$yang memiliki mobilitas yang baik didalam larutan dapat menimbulkan medan listrik sehingga konduktivitas membran reseptor meningkat. Sinyal pada buffer fosfat dan buffer fosfat-KCl pada kedua sensor lebih rendah daripada sinyal pada $\mathrm{HCl}$. Hal tersebut akibat dari kekuatan ion di dalam larutan, medan magnet dari $\mathrm{Fe}_{3} \mathrm{O}_{4}$ dapat menarik ion-ion ke permukaan membran sehingga akan membentuk lapisan ganda listrik (electrical double layer). Jika lapisan ganda listrik (electrical double layer) yang dihasilkan lebih tebal, maka akan menghasilkan kapasitansi dan menurunkan konduktivitas permukaan. Hal tersebut mengakibatkan beda potensial membran menjadi lebih rendah. Penurunan beda potensial membran berbanding lurus dengan penurunan sinyal.

Elektrolit di dalam larutan juga dapat mempengaruhi besarnya potensial elektroda pembanding $\mathrm{Ag} / \mathrm{AgCl}$. Hal tersebut dikarenakan elektroda pembanding merespon anion didalam larutan sehingga sinyal yang dihasilkan berbeda untuk setiap larutan elektrolit. Dalam larutan $\mathrm{HCl}$ $\mathrm{pH} 2$ dengan konsentrasi $\mathrm{Cl}^{-}$sebesar $1 \times 10^{-2} \mathrm{M}$ potensial sel elektroda pembanding yang dihasilkan sebesar $341 \mathrm{mV}$, untuk larutan buffer fosfat- $\mathrm{KCl} \mathrm{pH} 2$ konsentrasi $\mathrm{Cl}^{-}$di dalam larutan sebesar $1 \times 10^{-5} \mathrm{M}$ potensial sel elektroda pembanding sebesar $518 \mathrm{mV}$, untuk larutan buffer fosfat pH 2 elektroda pembanding merespon adanya ion fosfat yang memiliki konsentrasi $1 \times 10^{-4} \mathrm{M}$ potensial sel elektroda pembanding yang dihasilkan sebesar $459 \mathrm{mV}$. Sedangkan di dalam larutan $\mathrm{HCl} \mathrm{pH} 6$ dengan konsentrasi $\mathrm{Cl}^{-}$sebesar $1 \times 10^{-6} \mathrm{M}$ potensial sel elektroda pembanding yang dihasilkan sebesar $577 \mathrm{mV}$, untuk larutan buffer fosfat-KCl pH 6 konsentrasi $\mathrm{Cl}^{-}$di dalam larutan sebesar $1 \times 10^{-5} \mathrm{M}$ potensial sel elektroda pembanding sebesar $518 \mathrm{mV}$, untuk larutan buffer fosfat $\mathrm{pH} 6$ elektroda pembanding merespon adanya ion fosfat yang memiliki konsentrasi $1 \times 10^{-4} \mathrm{M}$ potensial sel elektroda pembanding yang dihasilkan sebesar $459 \mathrm{mV}$. Berdasarkan teori, jika potensial pembanding meningkat, maka sinyal yang dihasilkan akan mengalami penurunan [17]. Namun, pada sensor klorpirifos dalam $\mathrm{HCl}$ dihasilkan sinyal yang lebih besar karena konsentrasi $\mathrm{HCl}$ yang sangat rendah sehingga dimungkinkan $\mathrm{Cl}^{-}$tidak di respon oleh elektroda pembanding $\mathrm{Ag} / \mathrm{AgCl}$. Kepekaan sensor diazinon dan klorpirifos dapat dilihat pada tabel 2. Kepekaan sensor diazinon optimum yang dihasilkan yaitu $33,8 \mathrm{mV} /$ dekade, pada buffer fosfat-KCl $\mathrm{pH} 2$ dengan rentang konsentrasi $10^{-12}-10^{-5} \mathrm{M}$ dan waktu respon 150 detik. Sedangkan untuk sensor klorpirifos kepekaan sensor optimum yang dihasilkan sebesar $24 \mathrm{mV} /$ dekade, pada buffer fosfat pH 6 dengan rentang konsentrasi $10^{-13}-10^{-6} \mathrm{M}$ dan waktu respon 150 detik.

Tabel 2. Kepekaan sensor diazinon dan klorpirifos dalam masing-masing kondisi

\begin{tabular}{lcc}
\hline \multicolumn{1}{c}{ Kondisi } & \multicolumn{2}{c}{ Kepekaan sensor (mV/dekade) } \\
& Sensor diazinon & Sensor klorpirifos \\
\hline $\mathrm{HCl}$ & 10,7 & 11,6 \\
Buffer fosfat & 1,4 & 24 \\
Buffer fosfat-KCl & 33,8 & 17 \\
\hline
\end{tabular}




\section{Kesimpulan}

Elektrolit dalam larutan berpengaruh terhadap sinyal yang dihasilkan pada sensor pestisida diazinon dan klorpirifos. Sinyal terbesar yang dihasilkan oleh sensor diazinon dan klorpirifos adalah pada $\mathrm{HCl}$. Kepekaan sensor diazinon terbaik dihasilkan pada kondisi larutan buffer fosfat$\mathrm{KCl}$ pH 2 adalah 33,8 mV/dekade pada rentang konsentrasi $10^{-12}-10^{-5} \mathrm{M}$ dan waktu respon 150 detik. Kepekaan sensor klorpirifos terbaik dihasilkan pada kondisi larutan buffer fosfat $\mathrm{pH} 6$ adalah $24 \mathrm{mV} /$ detik pada rentang konsentrasi $10^{-13}-10^{-6} \mathrm{M}$ dan waktu respon 150 detik.

\section{Referensi}

[1] Sarangapani, C., N.N. Misra, V. Milosavljevic, P. Bourke, F. O'Regan, and P.J. Cullen, 2016, Pesticide degradation in water using atmospheric air cold plasma, J. Water Process Eng., vol. 9, hal. 225-232.

[2] Uchendu, C., 2012, The organophosphate, chlorpyrifos, oxidative stress and the role of some antioxidants: A review, African J. Agric. Reseearch, vol. 7, no. 18.

[3] Toft, P., 2004, Chlorpyrifos in Drinking-water Background document for development of WHO Guidelines for Drinking-water Quality, Chem. hazards Drink., hal. 1-6.

[4] Badan Standarisasi Nasional, 2008, "Batas maksimum residu pestisida pada hasil pertanian", SNI, vol. 7313, no. 2008, hal. 70-79.

[5] Pramana, D., A. Mulyasuryani, and R. Triandi Tjahjanto, 2018, "Membranes of Nata de coco-nanoparticles $\mathrm{Fe}_{3} \mathrm{O}_{4}$ For Diazinon Sensors", J. Pure Appl. Chem. Res., vol. 7, no. 3, hal. 275-281.

[6] Eggins, B.R., 2004, Analytical Techniques in the Science - Chemical Sensor and Biosensor.

[7] Li, S., Y. Ge, S.A. Piletski, and J. Lunec, 2012, Molecularly Imprinted Sensors : Overview and Applications. Oxford, UK: Elsevier.

[8] Liang, R.N., Q. Gao, and W. Qin, 2012, Potentiometric sensor based on molecularly imprinted polymers for rapid determination of clenbuterol in pig urine, Fenxi Huaxuel Chinese J. Anal. Chem., vol. 40, no. 3, hal. 354-358.

[9] Javanbakht, M., S.E. Fard, A. Mohammadi, M. Abdouss, M.R. Ganjali, P. Norouzi, and L. Safaraliee, 2008, Molecularly imprinted polymer based potentiometric sensor for the determination of hydroxyzine in tablets and biological fluids, Anal. Chim. Acta, vol. 612, no. 1, hal. 65-74.

[10] Smolinska-Kempisty, K., O.S. Ahmad, A. Guerreiro, K. Karim, E. Piletska, and S. Piletsky, 2017, New potentiometric sensor based on molecularly imprinted nanoparticles for cocaine detection, Biosens. Bioelectron., vol. 96, hal. 49-54.

[11] Liang, R., R. Zhang, and W. Qin, 2009, Potentiometric sensor based on molecularly imprinted polymer for determination of melamine in milk, Sensors Actuators, B Chem., vol. 141, hal. 544-550.

[12] Patachia, S., C. Croitoru, and G. Moise, 2009, Molecularly Imprinted Poly (Vinyl Alcohol) Films for the Selective Absorption of Glycyrrhizinic Acid From Aqueous Solutions, Environ. Eng. Manag. J., vol. 8, no. 4, hal. 663.

[13] Wu, N.L., S.Y. Wang, C.Y. Han, D.S. Wu, and L.R. Shiue, 2003, Electrochemical capacitor of magnetite in aqueous electrolytes, J. Power Sources, vol. 113, no. 1, hal. 173178.

[14] Abdallah, N.A., H.F. Ibhrahim, and N.H. Hegabe, 2017, Comparative study of molecularly imprinted polymer and magnetic molecular imprinted nanoparticles as recognition sites for the potentiometric determination of gemifloxacin mesylate, Int. J. Electrochem. Sci., vol. 12, no. 11, hal. 10894-10910.

[15] Duan, G.W., J. Zhang, Y. Li, Y.M. Xu, F. Yin, and Y.Z. Fu, 2017, The preparation of 
$\mathrm{Fe}_{3} \mathrm{O}_{4} /$ molecular-imprinted nanocomposite and the application on the recognition and separation of glyphosate, Inorg. Nano-Metal Chem., vol. 47, no. 4, hal. 481-487.

[16] Kumar, N. and R.N. Goyal, 2017, Melamine/ $/ \mathrm{Fe}_{3} \mathrm{O}_{4}$ Nanoparticles Based Molecular Imprinted Highly Sensitive Sensor for Determination of Hydrochlorothiazide: An Antihypertensive Drug, vol. 164, no. 6, hal. 240-246.

[17] Harvey, D., 2000, Modern Analytical Chemistry. 